\title{
Correction to: Effects of combined escitalopram and aripiprazole in rats: role of the $5-\mathrm{HT}_{1 \mathrm{a}}$ receptor
}

\section{Thomas Lapointe $^{1} \cdot$ Roger Hudson $^{1} \cdot$ Stephen Daniels $^{1} \cdot$ Brett Melanson $^{1} \cdot$ Yan $_{\text {Zhou }}{ }^{2} \cdot$ Francesco Leri $^{1}$}

Published online: 22 May 2019

(C) Springer-Verlag GmbH Germany, part of Springer Nature 2019

\section{Correction to: Psychopharmacology}

https://doi.org/10.1007/s00213-019-05225-z

After publication of this paper, the authors determined an error in Fig. 3. Below is the correct Fig. 3.

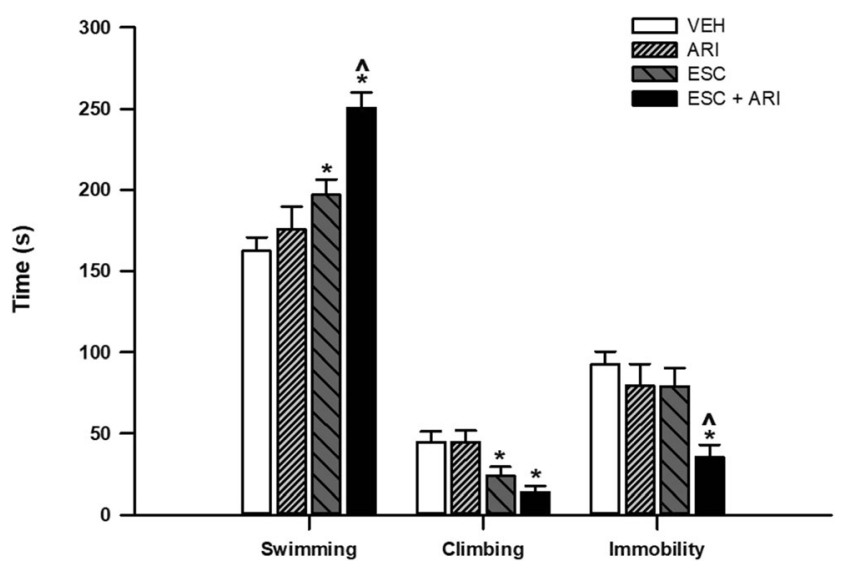

Publisher's note Springer Nature remains neutral with regard to jurisdictional claims in published maps and institutional affiliations.

The online version of the original article can be found at https://doi.org/ $10.1007 / \mathrm{s} 00213-019-05225-\mathrm{z}$

Francesco Leri

fleri@uoguelph.ca

1 Department of Psychology, Neuroscience Specialization, University of Guelph, Guelph, ON N1G 2W1, Canada

2 Laboratory of Addictive Diseases, Rockefeller University, New York, NY, USA 